\title{
STUDI KOMPARASI TERAPI KOMPLEMENTER YOGA DAN TERAPI MODALITAS AKTIVITAS KELOMPOK TERHADAP KEMAMPUAN MENGENDALIKAN HALUSINASI PENDENGARAN DI RUMAH SAKIT KHUSUS PROVINSI SULAWESI SELATAN
}

\author{
Indirawaty ${ }^{1}$, Rahman ${ }^{2}$, Sumirah $\mathrm{BP}^{3}$, Khaerunnisa ${ }^{4}$ \\ ${ }^{1,2}$ Dosen Politeknik Kesehatan Kementerian Kesehatan Makassar \\ ${ }^{3}$ Dosen Politeknik Kesehatan Kementerian Kesehatan Malang \\ ${ }^{4}$ Mahasiswa Politeknik Kesehatan Kementerian Kesehatan Makassar \\ *e-mail: indirawaty13@gmail.com
}

\begin{abstract}
ABSTRAK
Penelitian ini bertujuan untuk mengetahui pengaruh terapi komplementer dari meditasi yoga pada pasien stres di jiwa psikis Rumah Sakit Daerah Khusus Provinsi Sulawesi Selatan. Rancangan penelitian True Experimen Design True Experimental Design. Populasi dalam penelitian ini semua pasien stres yang datang untuk mengunjungi di rumah sakit khusus poliklinik Provinsi Sulawesi Selatan sebesar 60 responden yang terdiri dari 30 responden pada kelompok tanpa intervensi 30 orang untuk kelompok intervensi. Tes statistik meliputi: Tes Mann Whiteney dan uji Wilcoxon. Hasil uji analisis ini diperoleh data bahwa nilai hasil menunjukkan bahwa Ha ditolak dan Ho diterima yang artinya tidak ada perbedaan tingkat stres rata-rata pada kelompok tanpa intervensi dan intervensi kelompok selama pretest. Hasilnya menunjukkan bahwa Ha diterima dan Ho ditolak yang berarti ada perbedaan ratarata tingkat stres dalam kelompok tanpa intervensi dan kelompok intervensi pada posttest. Hasil uji statistik di atas memberikan kita gambaran bahwa ada dua kelompok dalam penelitian ini, kelompok responden diobati hanya dengan terapi farmakologi, dan satu kelompok responden yang diobati dengan terapi farmakologis dan terapi komplementer meditasi yoga. Yoga meditasi adalah latihan mental yang dapat menyeimbangkan fisik, emosional, mental, dan spiritual seseorang. Orang bermeditasi untuk mengurangi kecemasan, stres, dan depresi. Kedamaian jiwa yang diperoleh melalui meditasi yang baik akan meringankan stres dan memungkinkan seseorang untuk berpikir lebih jernih. Hasil penelitian menunjukkan bahwa kelompok yang diberikan terapi farmakologis dan terapi komplementer memiliki tingkat kesembuhan yang jauh lebih tinggi daripada kelompok responden yang hanya menerima terapi farmakologis.

Kata Kunci: Terapi Komplementer, Meditasi Yoga, Stress
\end{abstract}

\section{ABSTRACT}

This study aims to determine the effect of complementary therapies of yoga meditation on stress patients in the psychic soul of the Regional Special Hospital of South Sulawesi Province. True Experiment Design Design True Experimental Design design. The population in this study all the stress patients who came to visit in polyclinic special hospital of South Sulawesi province amounted to 60 respondents consisting of 30 respondents in the group without intervention 30 people for the Sugiono intervention group. The statistical tests include: Mann Whiteney test and Wilcoxon test. Result of analysis test using Mann Whiteney got data that result value indicated that Ha rejected and Ho accepted which mean there is no difference of average of stress level in group without intervention and intervention group during pretest. Result of analysis test The result shows that Ha accepted and Ho is rejected which means there is difference of average of stress level in group without intervention and intervention group at posttest. The above statistic test result give us picture that there are two 
groups in this research, that is group of respondents treated only with pharmacological therapy, and one group of respondents treated with pharmacological therapy and complementary therapies of yoga meditation. The results showed that the group given pharmacological therapy and complementary therapies had a much higher cure rate than the group of respondents who received only pharmacological therapy.

Keywords: Complementary therapies, Yoga meditation, Stress

\section{PENDAHULUAN}

Menurut data WHO (2011), orang dengan gangguan mental menempati tingkat yang luar biasa. Lebih dari 24 juta orang mengalami gangguan mental yang parah. Indonesia menjadi peringkat pertama dengan gangguan mental terbanyak. Berdasarkan data penelitian kesehatan dasar (Riskesdas, 2013), prevalensi gangguan jiwa berat pada populasi Indonesia 1,7 permil. Gangguan mental berat utama di Yogyakarta $(2,7 \%)$, Aceh (2,7\%), Sulawesi Selata (2,6\%), Bali $(2,3 \%)$ dan Jawa Tengah (2,3\%). Gangguan jiwa di Sulawesi Utara saja $0,8 \%$.

Salah satu gangguan mental yang dimaksud adalah skizofrenia. Gangguan perseptual utama pada pasien skizofrenia adalah halusinasi, jadi halusinasi adalah bagian dari kehidupan pasien. Pasien yang mengalami halusinasi biasanya mengalami gangguan dalam menilai dan memilih sehingga perilaku pasien sulit dipahami. Pasien dengan gangguan psikotik psikotik mengalami gangguan dalam mengidentifikasi rangsangan internal dan eksternal, tidak dapat membedakan delusi dan fakta dan percakapan pasien tidak sesuai dengan kenyataan. Ini menyebabkan pasien merasa asing dan memicu terjadinya kecemasan pada pasien (Keliat, 2004).

Terapi aktivitas kelompok adalah salah satu modalitas terapi yang dilakukan oleh perawat untuk sekelompok pasien yang memiliki masalah keperawatan serupa. Terapi aktivitas kelompok sering digunakan dalam praktek kesehatan mental, bahkan terapi kelompok saat ini adalah kegiatan penting dari keterampilan terapeutik dalam keperawatan (Keliat, 2004). Hasil penelitian yang dilakukan oleh Isnaeni (2008) tentang "Efektifitas Kegiatan Kelompok Terapi Stimulasi Persepsi Hallucinations Terhadap Penurunan Kecemasan Mendengar Pasien Pasien", didapatkan perbedaan tingkat kecemasan pasien sebelum dilakukan terapi aktivitas Kelompok dan setelah dilakukan Terapi Kegiatan Kelompok.

Terapi yoga dalam dunia keperawatan dikenal sebagai terapi komplementer. Terapi komplementer adalah cara mengobati penyakit sebagai dukungan untuk Pengobatan Medis Konvensional atau sebagai Pengobatan Pilihan Lain di luar Pengobatan Medis Konvensional. Berdasarkan data yang bersumber dari Organisasi Kesehatan Dunia pada $2005,75-80 \%$ populasi dunia pernah mengalami perawatan nonkonvensional. Menurut Majalah Kompas, Maret (2013). Data di Amerika Serikat menunjukkan bahwa 3\% pasien di sana melakukan terapi keseimbangan jiwa dan raga karena rekomendasi dokter mereka. Pada 2007, 38\% orang Amerika menggunakan pengobatan alternatif dan komplementer. Terapi keseimbangan tubuh dan jiwa, seperti yoga atau tai-chi yang mulai dikenal sejak tahun 2002. Saat ini, popularitas telah meningkat menjadi $75 \%$. Setelah disurvei, ternyata lebih dari $3 \%$ orang melakukan terapi atas saran dokter mereka. Penelitian ini dilakukan berdasarkan Survei Wawancara Kesehatan Nasional 2007 dari 23.000 rumah tangga. Hasil survei menunjukkan bahwa 6,3 juta orang menggunakan terapi keseimbangan jiwa dan raga berdasarkan rekomendasi dokter dan 34,8\% melakukannya atas inisiatif mereka sendiri. Kelompok yang mengikuti saran dokter umumnya memiliki kesehatan yang lebih buruk. "Para dokter menyarankan pasien untuk melakukan 
terapi komplementer sebagai upaya terakhir ketika terapi konvensional gagal, jadi kami menduga jika terapi komplementer dilakukan sejak awal mereka mungkin lebih baik," kata Dr Aditi Nerurkar dari Harvard Medical School yang melakukan penelitian.

Sekarang semakin banyak dokter yang tidak hanya mengandalkan obatobatan farmasi untuk menyembuhkan pasien mereka, tetapi juga terapi komplementer seperti yoga atau meditasi. Kecenderungan yang sama juga bisa dilihat di daerah perkotaan di Indonesia.

Meski tidak dianjurkan dokter, terapi komplementer seperti yoga atau meditasi kini makin mudah ditemukan, bahkan termasuk dalam program di pusat kebugaran. Menurut dr. Surjo Dharmono, Sp.KJ (K) dari Departemen Psikiatri Fakultas Kedokteran Universitas Indonesia, terapi meditasi seperti itu dianjurkan kepada pasien untuk tidak mengobati penyakit, tetapi tujuannya adalah untuk mengurangi stres karena penyakit yang diderita. Ketika stres berkurang, sistem kekebalan tubuh akan meningkat sehingga penyakit ini diharapkan dapat sembuh lebih cepat.

Meditasi yoga adalah latihan mental yang dapat menyeimbangkan fisik, emosional, mental, dan spiritual seseorang. Orang bermeditasi untuk mengurangi kecemasan, stres, dan depresi. Kedamaian jiwa yang diperoleh melalui meditasi yang baik akan meringankan stres dan memungkinkan seseorang untuk berpikir lebih jernih. Jadi ketika seseorang menghadapi masalah di mana diperlukan untuk dapat menemukan solusi. Banyak penelitian telah menunjukkan bahwa orang secara rutin melakukan meditasi Yoga dalam kehidupan sehari-hari terlihat percaya diri dan berwibawa. Para ahli di bidang medis percaya bahwa jika meditasi secara klinis terbukti menormalkan tekanan darah, detak jantung dengan menurunkan frekuensi pernapasan sehingga kebutuhan oksigen dapat dikurangi. Seiring dengan relaksasi pikiran, jiwa, dan emosi seseorang, tingkat stres juga akan berkurang. Meditasi adalah teknik untuk menormalkan fungsi otak yang memengaruhi suasana hati dan perasaan atau perasaan kita. Dengan meditasi penyakit yang paling tepat yang berasal dari pikiran manusia dapat dikendalikan dengan baik.

Menurut catatan medis Rumah Sakit Khusus Provinsi Sulawesi Selatan jumlah pasien gangguan jiwa telah meningkat dari tahun ke tahun ini dibuktikan pada tahun 2005 ada sekitar 400 orang dengan gangguan mental, pada tahun 2006 naik menjadi 563 pasien dan pada tahun 2007 meningkat menjadi 592 orang. Dan yang paling pengecut adalah data tahun 2011 dimana peningkatan presentasi gangguan mental sebanyak 11.353 orang.

Rumah Sakit Daerah Khusus Provinsi Sulawesi Selatan terdiri dari rumah sakit pusat stroke dan rumah sakit jiwa dengan tipe A, dan merupakan rumah sakit rujukan Indonesia Timur. Rumah Sakit Jiwa Makassar terletak di tengah kota dan merupakan rumah sakit tertua di Indonesia.

Berdasarkan data yang digambarkan di atas gangguan mental telah meningkat dari tahun ke tahun yang membutuhkan penanganan serius, untuk mencari solusi kemudian, peneliti ingin membuktikan bahwa terapi komplementer yoga meditasi dapat membantu pasien psikiatri, terutama mereka yang mengalami gangguan kognitif: halusinasi pendengaran.

\section{METODE}

Metodologi penelitian ini ialah peneliti menguraikan tentang jenis penelitian, subjek atau objek, variable, cara pengumpulan data dan teknik analisis data, serta waktu dan lokasi penelitian secara jelas. Metode penelitian harus menjelaskan secara utuh tahap penelitian yang jelas, luaran indicator, capaian yang terukur disetiap tahap. Terdapat penjelasan yang lebih rinci pada bagian instrument 
pengumpulan data, bahan dan prosedur kerja dan teknik analisisnya.

Desain penelitian yang digunakan adalah Quasi experimental dengan rancangan perbandingan kelompok statis (statis group comparism) yaitu kelompok intervensi pertama menerima perlakukan (X1), kemudian dilakukan pengukuran, hasilnya dibandingkan dengan kelompok intervensi kedua yang menerima perlakuan (X2). Pada penelitian ini, membandingkan dua kelompok intervensi, satu kelompok intervensi penerima perlakuan pemberian Yoga, dan satu lagi menerima perlakuan pemberian terapi aktivitas kelompok. Desain Penelitian Quasi Experiment dengan kelompok statis.

Populasi adalah seluruh subjek atau objek dengan karakteristik tertentu yang akan diteliti. Subjek penelitian ini adalah seluruh pasien halusinasi pendengaran yang dirawat di bangsal. Subjek dalam penelitian ini sebanyak 60 orang.

Sampel penelitian adalah sebagian objek yang diteliti dan dianggap mewakili seluruh populasi, Notoatmodjo (2008). Objek dalam penelitian ini berjumlah 60 responden, teknik pengambilan sampel dalam penelitian ini menggunakan teknik non probability sampling dengan pendekatan consecutive dengan cara semua subjek yang ada dan memenuhi kriteria sampel akan dipilih dalam penelitian ini sampai semua jumlah subjek yang diperlukan terpenuhi (Sastroasmoro \& Ismael, 2009) sampel penelitian ini mempunyai kriteria insklusi dan ekslusi.

\section{HASIL}

Gambaran terapi komplementer yoga terhadap kemampuan mengendalikan hallusinasi sebelum dan sesudah diberikan intervensi Yoga.

Sampel dalam penelitian ini sebanyak 30 responden yang diberikan intervensi Yoga yang hasilnya dapat tergambar pada Tabel 5.4. menunjukkan nilai $\mathrm{P}$ sebesar $0,000(<0,05)$, yang berarti bahwa ada perbedaan kemampuan mengendalikan halusinasi pada saat pretest dan posttest pada kelompok Yoga. Dimana variabel pretest memiliki nilai minimum 7 , maksimum 14 dan median 9. Sedangkan variabel posttest memiliki nilai minimum 16, maksimum 26 dan median 30. Hasil penelitian ini mengambarkan bahwa kemampuan mengendalikan hallusinasi setelah diberikan intervensi Yoga terjadi kenaikan minimum dari 7 menjadi 16, maksimum dari 14 menjadi 26, dan mediannya dari 9 menjadi 30, yang berarti ada kemajuan klien dalam mengendalikan hallusinasi setelah pelaksanaan terapi komplemneter Yoga. Hal ini sejalan dengan hasil review yang dilakukan terhadap 16 responden yang dilakukan menunjukkan bahwa jika melakukan yoga secara efektif memiliki efek positif bagi orang-orang dengan keluhan depresi dan susah tidur. Begitu juga dengan orangorang yang menderita skizofrenia dan ADHD. Dari kajian studi tersebut, praktek yoga mempengaruhi proses membawa pesan kimia dalam otak, peradangan tubuh dan faktor biologis lainnya. "Manfaat ini ternyata sama dengan obat antidepresan dan psikoterapi," kata peneliti Dr. P. Murali Doraiswamy, seorang profesor psikiatri dan kedokteran di Medical Centre Universitas Duke.

Gambaran terapi modalitas Terapi AKtivitas Kelompok terhadap kemampuan mengendalikan hallusinasi sebelum dan sesudah diberikan intervensi Terapi aktivitas kelompok modifikasi kuis siapa berani.

Sampel dalam penelitian ini sebanyak 30 pasien yang menderita hallusinasi pendengaran hal ini dapat tergambar pada Tabel 5.3. Hasil uji Wilxoson memberikan gambaran bahwa kemampuan mengendalikan halusinasi sebelum dan sesudah diberi intervensi pada kelompok Terapi Aktivitas Kelompok menunjukkan nilai $\mathrm{P}$ sebesar 0,000 (< $0,05)$, yang berarti bahwa ada perbedaan kemampuan mengendalikan halusinasi pada saat pretest dan posttest pada kelompok Terapi Aktivitas Kelompok, dimana variabel pretest memiliki nilai 
minimum 7, maksimum 14 dan median 8 . Sedangkan variabel posttest memiliki nilai minimum 12, maksimum 23 dan median 19.

Dari hasil penelitian ini mengambarkan bahwa sebelum pelaksanaan terapi aktivitas kelompok ke 30 pasien dilaksanakan pretest, dimana hasil pretes menunjukkan nilai minumun sebanyak 7, sedangkan setelah diadakan intervensi terapi aktivitas kelompok terjadi kenaikan nilai minimum sebanyak 23 , nilai minimum ini diperoleh dari jawaban hasil pengisian kuesioner yang menunjukkan kemampuan menjawab pertayaan yang paling rendah 7 yang memberi gambaran bahwa ada kemajuan mengendalikan hallusinasi setelah pasien mengikuti kegiatan terapi aktivitas kelompok modifikasi metode kuis siapa berani.

\section{PEMBAHASAN}

Terapi Komplementer merupakan cara penanggulangan penyakit yang dilakukan sebagai pendukung pengobatan medis konvensional atau sebagai pengobatan pilihan lain diluar pengobatan medis yang konvensional. Terapi Komplementer adalah semua terapi yang digunakan sebagai tambahan untuk terapi konvesional yang direkomendasikan oleh penyelenggara pelayanan kesehatan induvidu. WHO mendefinisikan Pengobatan Komplementer adalah pengobatan non konvensional yang bukan berasal dari Negara yang bersangkutan. Meditasi adalah latihan olah jiwa yang dapat menyeimbangkan fisik, emosi, mental dan spiritual seseorang. Dewasa ini, orang melakukan meditasi untuk mengurangi kecemasan, stress, dan depresi. Budi Payitno (2014) mengemukakan bahwa ketenagaan jiwa yang diperoleh melalui meditasi yang baik oleh sebagian orang diyakini akan meredakan stress dan memungkinkan seseorang menghadapi suatu masalah, dimana ia dituntut untuk bisa menemukan sebuah solusi, ia akan memberikan solusi terbaik. Ananda Krisna mengemukakan meditasi adalah kegiatan mental terstruktur dan dilakukan selama jangka waktu tertentu untuk menganalisis, menarik kesimpualan, dan mengambil langkahlangkah lebih lanjut untuk menyikapi, menentukan tindakan atau menyelesaikan masalah pribadi hidup dan perilaku, Dalam Kamus Besar Bahasa Indonesia, kata meditasi diartikan sebagai pemusatan pikiran dan perasaan untuk mencapai sesuatu. Dari segi etimologi meditasi berasal dari bahasa Latin yaitu meditatio artinya hal bertafakur, hal merenungkan, memikirkan, mempertimbangkan; atau latihan, pelajaran persiapan. Budi Prayitno (2014) mengemukakan bahwa dari segi terminology meditasi adalah penggunaan pikiran terus menerus untuk merenungkan beberapa kebenaran, misteri atau objek penghormatan yang bersifat keagamaan sebagai latihan ibadah. Kata yoga merupakan bahasa sanskerta. Berasal dari kata "Yuj", konon perkataan "Yoke" dalam bahasa Inggris atau "Juk", juga berasal dari kata kerja "Yuk". Jadi dapat dimaksudkan "Yuj" ini berarti sesuatu yang "menyatukan". Dengan demikian orang memerlukan "penyatuan" atau pemusatan tenaga dan pikiran untuk mencapai tujuan yang didambakan. Atau dengan kata lain berarti mengendalikan, mengatur, berkonsentrasi dan berfungsi menyelaraskan tubuh, jiwa dan pikiran kita. Yoga yang berarti penggabungan atau penyatuan (Kresna GL,2014). Menurut Widagdo (2013) bahwa Yoga merupakan latihan memperbaiki postur tubuh, memperkuat otot, melindungi tulangtulang punggung, mencegah osteoporosis, memperlancar aliran darah, melindungi jantung, membersihkan limfa, menurunkan tekanan darah, dan menurunkan gula darah.

Gangguan jiwa atau penyakit jiwa merupakan penyakit dengan multi kausal, suatu penyakit dengan berbagai penyebab yang sangat bervariasi. Kausa gangguan jiwa selama ini dikenali meliputi kausa pada area organobiologis, area psikoedukatif, dan area sosiokultural. 
Dalam konsep stress-adaptasi penyebab perilaku maladaptive dikostrukkan sebagai tahapan mulai adanya factor predisposisi, factor presipitasi dalam bentuk stressor pencetus, kemampuan penilaian terhadap stressor, sumber koping yang dimiliki, dan bagaimana mekanisme koping yang dipilih oleh seorang individu. Dari sini kemudian baru menentukan apakah perilaku individu tersebut adaptif atau maladaptive.

Banyak ahli dalam kesehatan jiwa memiliki persepsi yang berbeda-beda terhadap apa yang dimaksud gangguan jiwa dan bagaimana gangguan perilaku terjadi. Perbedaan pandangan tersebut tertuang dalam bentuk model konseptual kesehatan jiwa. Pandangan model psikoanalisa berbeda dengan pandangan model social, model perilaku, model eksistensial, model medical, berbeda pula dengan model stress-adaptasi. Masingmasing model memiliki pendekatan unik dalam terapi gangguan jiwa. Berbagai pendekatan penanganan klien gangguan jiwa inilah yang dimaksud dengan terapi modalitas. Suatu pendekatan penanganan klien gangguan yang bervariasi yang bertujuan mengubah perilaku klien gangguan jiwa dengan perilaku maladaptifnya menjadi perilaku yang adaptif. (Stuart \& Sundenn, 1998) Halusinasi adalah gangguan penyerapan (persepsi) panca indera tanpa adanya rangsangan dari luar yang dapat meliputi semua sistem penginderaan dimana terjadi pada saat individu sadar dengan baik. (Townsend, 2002) Halusinasi atau salah persepsi indrawi yang tidak berhubungan dengan stimulus eksternal yang nyata, mungkin melibatkan salah satu dari lima indra. Halusinasi yaitu gangguan persepsi (proses penyerapan) pada panca indera tanpa adanya rangsangan dari luar, pada pasien dalam keadaan sadar.

Pada gangguan jiwa skizofrenia, halusinasi pendengaran merupakan hal yang paling sering terjadi, dapat berupa suara-suara bising atau kata-kata yang dapat mempengaruhi tingkah laku, sehingga dapat menimbulkan respon tertentu seperti bicara sendiri, marah, atau berespon lain yang membahayakan diri sendiri, orang lain, dan lingkungan. Hal serupa dapat bersikap mengamati orang lain yang tidak bicara atau benda mati yang seakan-akan berbicara padanya. (Nasution, 2003) Halusinasi merupakan tanda khas dari gangguan skhizofrenia dan merupakan manifestasi dari metankolia involusi, psikosa, depresi, dan sindrom otak organik.

\section{KESIMPULAN}

Terapi komplementer adalah terapi yang digunakan secara bersama-sama dengan terapi lain dan bukan untuk menggantikan terapi medis. Meningkatkan kesehatan dan kesejahteraan. Terapi komplementer bertujuan untuk mengendalikan hallusinasi pada pasien, sehingga meningkatkan kesehatan, mencegah penyakit, menghindari atau meminimalkan efek samping, gejalagejala, dan atau mengontrol serta menyembuhkan penyakit.

\section{SARAN}

Diharapkan Peran Perawat dalam Terapi Komplementer ialah sebagai pelaku dari terapi komplementer selain dokter dan praktisi terapi, sehingga diharapkan terapi komplenter meditasi yoga dan Task diprogram (dimasukkan sebagai intervensi keperawatan jiwa yang ada di setiap tatanan pelayanan kesehatan jiwa sebagai terapi nonfarmakologi), yang meliputi pendekatan perilaku, pendekatan kognitif, serta relaksasi. salah satu jenis terapi yang dapat menimbulkan relaksasi sehingga dapat mengontrol hallusinasi pendengaran

Dengan penelitian ini diharapkan menghasilkan pedoman (modul untuk perawat) sebagai pedoman dalam pelaksanaan terapi komplementer meditasi yoga dan modul terapi komplementer aktivitas kelompok dengan modifikasi metode kuis siapa berani. 


\section{KEPUSTAKAAN}

Daley, Debra. 2011. 30 Menit Untuk Bugar dan Sehat. Penerbit: Bhuana Ilmu Gramedia

Hidayat, Aziz Alimul. 2007. Riset Keperawatan dan Teknik PenulisanIlmiah. Penerbit: Salemba Medika.

Lebang, Erikar. 2014. Yoga Sehari-hari. Penerbit: Pustaka Bunda.

Notoatmodjo, Soekijo. 2010. Kesehatan. Jakarta: Penerbit Gramedia Pustaka Utama

Notoatmodjo, Soekijo. 2010. Metodologi Penelitian Kesehatan. Jakarta: Penerbit Gramedia Pustaka Utama.

Prayitno, Budi. 2014. Meditasi Penyembuhan dari Dalam. Penerbit: Flashbooks.

Riduwan. 2009. Skala Pengukuran Variabel-variabel Penelitian. Penerbit: Alfbeta Bandung.
Rokhmah, R, N. 2010. Hubungan Meditasi dalam Yoga dengan Daya Tahan Terhadap Stress Pada Paguyuban Yogiswaran Surakarta. http://etd. eprints. ums.ac.id/858/. Diakses jumat 7 Februari 2015.

Saryono. 2011. Metodologi Penelitian Kesehatan: Penuntun Praktis Bagi Pemula. Bandung: PT Refika Aditama

Setiadi. 2007. Riset Keperawatan. Surabaya: Penerbit Graha Ilmu.

Sindhu, P. 2009. Yoga Untuk Kehamilan Sehat, Bahagia dan Penuh Makna. Bandung: Penerbit Mizan Pustaka.

Siska, Connie. 2010. Statistik Kesehatan. Edisi Revisi. Jakarta: Rajawali Pers.

Sugiyono,2011, Metode Penelitian Kombinasi (Mixed Methods. Bandung: PT Refika Aditama

Yosep I. 2009. Keperawatan Jiwa. Bandung: PT Refika Aditama 